\title{
A laktózintoleranciáról: Múlt és jelen - II. rész
}

\author{
Buzás György Miklós dr. \\ Ferencvárosi Egészségügyi Szolgáltató Kiemelten Közhasznú Nonprofit Kft., Budapest
}

\begin{abstract}
A szerző a laktózintolerancia, a kalcium- és D-vitamin-anyagcsere és az osteoporosis összefüggéseit foglalja össze. A laktózintolerancia egyes betegcsoportokban fokozza az alkar- és csípőtörések kockázatát. Néhány népcsoportban összefüggés van a laktázgén genotípusa és a töréskockázat között. A kalcium- és D-vitamin-pótlás növeli a csontok ásványianyag-mennyiségét, ezért e vitaminok fogyasztása indokolt gyermekeknél, terhességben, a szoptatás alatt, illetve a menopauza után. A tej és tejtermékek fogyasztása növelheti a petefészekrák kockázatát. Finneknél a laktázgén CC genotípusa növelte, brit, spanyol és olasz egyéneknél nem befolyásolta a colorectalis rák kockázatát. Egyéni érzékenység alapján a gyógyszerekben lévő kis mennyiségű (10-750 mg) laktóz is okozhat tüneteket. A közhiedelemmel és a reklámmal ellentétben a kontrollált tanulmányok sem a diéta, sem az enzimpótlás, sem a probiotikumok hatását nem igazolták az evidenciák színvonalán. Mivel elfogadott irányelvek nincsenek, a tejcukor-érzékenység egyénre szabott terápiája választandó. A fokozódó érdeklődés ellenére a laktózintoleranciában még sok ismeretlen tényező hatását kell tovább kutatni. Orv. Hetil., 2015, 156(43), 1741-1749.
\end{abstract}

Kulcsszavak: daganatok, enzimpótlás, laktóz, osteoporosis, probiotikumok

\section{Lactose intolerance: past and present. Part II}

The author summarises the interrelations between lactose intolerance, calcium and vitamin D metabolism and osteoporosis. Lactose intolerance enhances the risk of forearm and hip fractures in some patients. Lactase gene genotype and fracture risk are related in some populations. Calcium and vitamin D supplementation increase bone mineral content and they are justified in children, during pregnancy and lactation, and in postmenopausal women. The intake of milk and milk products could increase the risk of ovarian carcinoma. CC genotype of the lactase gene increased the risk of colorectal carcinoma in Finns; no such effect was observed in British, Spanish and Italian patients. Even small quantities of lactose in drugs $(10-750 \mathrm{mg})$ could elicit intolerance symptoms due to individual susceptibility. In spite of public knowledge and advertising, controlled studies did not prove the beneficial effect of either a lactosefree diet, enzyme supplementation or probiotics in an evidence-based manner. While accepted guidelines are lacking, a personalised therapy is mandatory. In spite of increasing public interest in lactose intolerance, many unknown factors must still be studied.

Keywords: enzyme supplementation, lactose, osteoporosis, probiotics, tumours

Buzás, Gy. M. [Lactose intolerance: past and present. Part II]. Orv. Hetil., 2015, 156(43), 1741-1749.

(Beérkezett: 2015. augusztus 18.; elfogadva: 2015. szeptember 10.)

\section{Rövidítések}

5-FU = 5-fluorouracil; CFU = (colony forming unit) telepképző egység; CRC = colorectalis carcinoma; DEXA = dual energy $\mathrm{X}$-ray absorbtiometry; $\mathrm{DM}=$ diabetes mellitus; IGF- 1 = inzulinszerü növekedési faktor 1 -es típus; $\mathrm{KT}=$ konfidenciatartomány; LI = laktózintolerancia; NIH = National Institute of Health; OÉTI = Országos Élelmezés- és Táplálkozástudomá- nyi Intézet; OGYI: Országos Gyógyszerészeti Intézet; OR = (odds ratio) esélyhányados; $\mathrm{RR}=$ relatív kockázat; UDP $=$ uridinil-difoszfát

A laktózintolerancia (LI) széles körü elterjedése révén hozzájárulhat az osteoporosis kialakulásához, társulhat 
daganatokkal és befolyásolhatja az életminőséget. Kezelése komplex, nem mentes az ellentmondásoktól, tévhitektől $[1,2]$.

\section{Laktózintolerancia, kalcium-anyagcsere, D-vitamin és osteoporosis}

A legáltalánosabban fogyasztott tehéntej jelentős tápanyag, kalória-, ásványianyag- és vitaminforrás: legfontosabb összetevóit az 1. táblázatban tüntetjük fel. A modern tejfeldolgozó ipar számos terméket állít elő: ezek összetétele változó, ismertetésük meghaladja e közlemény kereteit és a táplálkozástudomány feladata. A tejben $87 \%$ víz és 13\% más vegyület található, kémiailag komplex oldatot alkotva, amelyben jelen vannak az ionos, molekuláris, kolloid és emulziós összetevők [3] (1. táblázat). A tej és tejtermékek kiváló kalciumforrást képviselnek, mivel a kalcium koncentrációja magas, biohasznosulása jó és ráadásul olcsó $[4,5] .200 \mathrm{ml}$ tej 2500 mg kalciumot tartalmaz, napi 3-4 pohár fogyasztása biztosítja a javasolt napi szükségletet: ugyanennyi kalciumot 5-7 adag zöldség vagy 10-12 adag teljes kiőrlésű gabona biztosítaná. Az átlagos táplálkozásban a tejtermékek a kalciumbevitel 52-65\%-át, a fehérje 20-28\%-át biztosítják.

1. táblázat |A tehéntej összetétele

\begin{tabular}{|c|c|c|c|}
\hline Összetevő & Fizikai állapot & $\begin{array}{l}\text { Mennyiség } \\
\text { tehéntejben }\end{array}$ & $\begin{array}{l}\text { Energia- } \\
\text { tartalom }\end{array}$ \\
\hline Laktóz & Molekuláris oldat & $3,6-5,5 \mathrm{~g} \%$ & 4 kalória/g \\
\hline $\begin{array}{l}\text { Zsiradék } \\
\text { (trigliceridek) }\end{array}$ & Emulzió & $2,5-6,0 \mathrm{~g} \%$ & 9 kalória/g \\
\hline $\begin{array}{l}\text { Fehérje } \\
\text { (kazein) }\end{array}$ & Micelláris diszperzió & $2,9-5,0 \mathrm{~g} \%$ & 4,5 kalória/g \\
\hline Kalcium & $\begin{array}{l}\text { Molekuláris } \\
\text { (Ca-citrát, foszfát) } \\
\text { és kolloidoldat }\end{array}$ & $1320 \mathrm{mg} \%$ & - \\
\hline Magnézium & $\begin{array}{l}\text { Molekuláris oldat } \\
\text { (Mg-citrát) }\end{array}$ & $10,8 \mathrm{mg} \%$ & - \\
\hline Foszfor & $\begin{array}{l}\text { Molekuláris oldat } \\
\text { (Ca és Mg-foszfát) }\end{array}$ & $95,8 \mathrm{mg} \%$ & - \\
\hline D-vitamin & $\begin{array}{l}\text { Zsírokkal asszociált } \\
\text { emulzió }\end{array}$ & $\begin{array}{l}0,3-1,0 \mu \mathrm{g} / \\
\text { liter } \\
(15-40 \mathrm{IU})\end{array}$ & - \\
\hline
\end{tabular}

A táplálékkal bevitt kalcium túlnyomóan a duodenumban szívódik fel aktív, transcellularis és passzív, paracellularis mechanizmus által. A bél epithelialis sejtjeinek luminalis oldalán a kalcium speciális $\mathrm{Ca}^{2+}$-csatornán hatol be, a citoplazmában egy kalbindin nevü fehérjéhez kötődik, amely a basolateralis oldalra szállítja és átadja a $\mathrm{Ca}^{2+}$ dependens ATP-áznak. A paracellularis út passzív diffúzió révén a sejtek közti junctiókban történik. Az aktív transzport a duodenumban, a passzív a jejunumban és kisebb mértékben az ileumban történik. Magas kalciumbevitel esetén az aktív, alacsony bevitelben a passzív fel- szívódás dominál. A D-vitamin aktív formája, az 1,25(OH $)_{2}$-cholecalciferol a kalbindin gén túlszabályozása révén serkenti annak szintézisét és növeli az aktív és passzív transzportot a duodenumban, ileumban, sőt a colonban is $[3,4,5]$.

A bél lumenében jelen lévő szénhidrátok, így a laktóz és a xilóz, elősegítik a kalcium felszívódását gyermekekben és felnőttekben [6]. A prágai Károly Egyetemen magyar részvétellel 1973-ban mutatták ki, hogy a kalcium felszívódása csökkent az alacsony laktázaktivitású betegekben [7]. Utóbb ellentmondásos eredmények születtek, más szerzők éppenséggel azt észlelték, hogy LI-ben a csökkent kalciumbevitel miatt annak felszívódása növekszik $[8,9]$.

1967-ben írták le, hogy LI-ben a csökkent kalciumbevitel miatt az osteoporosis kockázata a többszörösére növekszik (OR: 7,53, 95\% KT: 1,30-43,98) [8]. 1978ban $\mathrm{H}_{2}$-kilégzési teszttel 31 osteoporosisos betegnél 26\%-ban, 31 kontroll esetében 3\%-ban észleltek LI-t [10]. Egy másik tanulmányban 46, posztmenopauzában lévő osteoporosisos betegnél az LI gyakorisága 54\%, a kalciummalabsorptio aránya $44 \%$ volt [11]. E néhány adat alapján levonták a következtetést, hogy a csökkent kalciumfelszívódás miatt a tejcukor-érzékenység az osteoporosis egyik kockázati tényezője. Az osteoporosis modern vizsgálati módszerei (DEXA, CT, a csont ásványianyag-tartalmának mérése) az 1980-as években jelentek meg, míg az LI-ben jelentkező csontanyagcsere és morfológiai elváltozásokról a kontrollált tanulmányok 2000 után születtek.

A „néma tolvajnak” is nevezett osteoporosist az 1993-as konszenzuskonferencia és a NIH szerint a csonttömeg és csontminőség csökkenése, továbbá a törések fokozott kockázata jellemzi. A betegséget 1750-ben írta le Joseph Guichard Duverney (1648-1730) anatómus-sebész, a XIV. Lajos (1638-1715) által alapított Jardin du Roi orvosi iskola tanára. A csonttörések fokozott kockázatára 1705-ben hívta fel a figyelmet Jean-Louis Petit (16741750), a párizsi Charité kórház sebésze. Az osteoporosis kifejezést ifjabb Johann Lobstein (1777-1835) strassburgi patológus-sebész adta 1820-ban: szerinte azt a csontok növekedése és a csontszövet ritkulása jellemzi, ezért úgy tartják, leírása inkább osteogenesis imperfectának felelt meg. A kifejezés a görög ostéon $=$ csont + póros $=$ pórus szavakból származik. Az osteomalaciát 1885-ben különítették el az osteoporosistól. 1882-ben írták le, hogy az osteoporosis elsősorban menopauza után jelentkezik, de csak 1941-ben figyelte meg az amerikai endokrinológia atyja, Fuller Albright (1900-1969), hogy petefészkek exstirpatiója után a csigolyatörések gyakoribbak. Paleopatológusok szerint a csontritkulást tévesen tartják a modern ember betegségének: őslénytani leletek sokasága igazolja, hogy az osteoporosis ismérvei már a több 1000 évvel ezelőtti csontmaradványokon felfedezhetők [12]. Józsa László patológus-paleopatológus szerint a Homo sapiens megjelenése után 135 000-155 000 évig a 
végtagi csontok tömege lassan, de fokozatosan csökkent. Az első osteoporosist egy bronzkorból származó, körülbelül 4-5 ezer éves női csonton mutatták ki. Az ókori csontok vizsgálatakor ugyanazokat a módszereket alkalmazzák, mint az emberi diagnosztikában (DEXA, CT, hisztomorfometria) [13]. Magyar vonatkozásban érdekes adatok várhatók a váci templomban 1735-1830 között temetett múmiák modern módszerekkel való feldolgozásától. A tejfogyasztás és a paleopatológiai adatok illesztése ez idáig a szakirodalomban nem történt meg, így nem tudható, hogy az mennyiben befolyásolta az idők folyamán az osteoporosis és a csonttörések alakulását.

A kalcium-anyagcsere fó szabályozó tényezője a D-vitamin. Az anyatejben jelentős mennyiségú D-vitamin található, a tehéntejben ehhez képest csökkent (1. táblázat). A táplálékokban (tej, hal, hús, olaj) a $\mathrm{D}_{3}$-vitamin és 4-5ször aktívabb 25-OH-D $\mathrm{D}_{3}$ keveréke van jelen, de nyomokban $\mathrm{D}_{2}$-vitamin is kimutatható. Megfelelő ultraibolya sugárzás mellett a táplálékban lévő D-vitaminokra nem is lenne szükség, de a modern életformában a fokozódó munkahelyi elfoglaltság miatt a napsütésben eltöltött idő csökken, így a táplálékban lévő D-vitaminra szükség van. A tehéntej D-vitamin-tartalma széles határok között változik az állat fajtája, táplálkozása és az évszakok szerint. Lévén zsíroldékony, a tejben micelláris formában van jelen, passzív diffúzió révén bekerül az enteralis hámsejtekbe, onnan a nyirokkeringésbe, ahol a kilomikronok szállítják, majd a célszövetekben kötődik a D-vitamin-receptorokhoz. Forralással, fózéssel a tej Dvitamin-tartalma kismértékben csökken [14]. Számos országban (Egyesült Államok, Kanada, arab országok) a tejet, tejtermékeket változó mennyiségü D-vitaminnal dúsítják.

$\mathrm{Az}$ alacsony laktóztartalmú étrend hatását a csontanyagcserére (törések, csontsúrűség, ásványianyag-tartalom) 55 dolgozatban, 233000 esetben értékelték ki. A tanulmányok módszertana, az esetszám különbözó volt, az elért adatok heterogének, a következtetések evidenciaszintje alacsony volt [2].

A csökkent laktóztartalmú étrendet fogyasztó felnőttek, az igazolt LI és az annak tüneteivel rendelkező betegeknél a csonttörések kockázata nagyobb volt, a nőknél magasabb, mint a férfiaknál. Különösen magas a kockázat gyermekeknél: a prepubertális korosztályban az alkar törésének kockázata (OR: 3,59, 95 KT: 1,77-7,23), az életkorhoz illesztett kockázat csökkent laktóztartalmú étrend fogyasztása esetében még magasabb (OR: 4,13, 95\% KT: 1,61-10,56). Szintén magasabb a töréskockázat a vegán étrendet fogyasztó felnőtteknél, de nem a vegetáriánusoknál és halevőknél (OR: 1,37, 95\% KT: 1,07-1,74) [15]. A European Mediterranean Osteoporosis Study, Canadian Multicenter Osteoporosis Study, National Health and Nutritional Examination Study, Rotterdam és Sheffield Study adatai mellett számos ki- sebb tanulmányban nem találtak összefüggést a tejtermék fogyasztása és a törési kockázat között.

A finn lakosságban a CC genotípusú egyéneknél a csípőtörés kockázata a TT genotípushoz képest 4,22 (95\% KT: 2,16-8,26), alkar/könyök törés esetében 2,82 (95\% KT: 1,52-5,49) [16]. Más nemzeteknél (osztrák, olasz) nem találtak összefüggést a laktázgenotípus és a törési kockázat között.

Hazai szerzőcsoport 595, posztmenopauzában lévő nőbetegnél a $\mathrm{C} / \mathrm{T}$ genotípus esetében csökkent kalcium- és csontásványianyag-szintet észlelt a TT és CC genotípushoz képest [17].

A csökkentett tejcukortartalmú vagy laktózmentes termékeket fogyasztó gyermekeknél és felnőtteknél mind a csontsűrüség, mind a csont ásványianyag-tartalma alacsonyabb volt, mint a kontrollcsoportokban, de jelentős földrajzi és etnikai különbségeket is észleltek. Nőknél a CC genotípus a TT-vel szemben csökkenti a csontsürüséget.

Kiindulva a tejtermékek fogyasztása és a csontanyagcsere komplex összefüggéséből, az utóbbi években több kontrollált tanulmány készült, amelyekben kimutatták, hogy pre- és posztmenopauzás nőknél a D-vitaminnal és kalciummal dúsított joghurt vagy sajt 2-12 hónapos fogyasztása csökkenti a csontreszorpció markereinek ürülését (deoxipirolidin, l-es típusú prokollagén N-propeptid, osteocalcin, l-es típusú inzulinszerü növekedési faktor, tartrátrezisztens acid-foszfatáz $5 \mathrm{~b}$ izoformája). A hosszabb időtartamú tanulmányokban leírták a csontásványianyagok növekedését a csípőízületekben, de a gerincben nem $[18,19,20]$. A Framingham tanulmányban joghurt fogyasztása mellett csökkent a csipőtörések kockázata [2]. Hasonló tanulmányok LI-ben azonban még nem készültek. Az Egyesült Államokban gazdasági felmérések szerint a tejtermékek napi 3-4-szeri fogyasztása 20\%-kal csökkentette az osteoporosis kivizsgálási és kezelési költségeit, és évente 3,5 milliárd dollár megtakarításához vezet. A tejtermékek fogyasztása a csípőtörések kezelési költségeinek csökkenését eredményezte (Franciaországban 129 millió, Svédországban 34 millió és Hollandiában 6 millió euró) [5].

\section{Laktózintolerancia és a daganatok}

Gyakorisága révén az LI társulhat daganatokkal: kérdés, hogy fokozza-e a tej és tejtermékek fogyasztása, illetve az LI a daganatok kockázatát. 1989-ben mutatták ki először az 1970-es években végzett felmérések alapján, hogy a fejenkénti tejfogyasztás, a becsült laktózperzisztencia aránya és a petefészekrák között pozitív összefüggés van [21], ezt utóbb több tanulmányban cáfolták. Svéd metaanalízisben 2006-ban mutatták ki, hogy a tejtermékek fogyasztása és a laktóz növelik e daganat kockázatát [22]. 2014-ben a Svéd Nemzeti Rákregiszter adatai alapján 22788 tejcukorérzékeny egyénben a tüdőrák (RR: 0,55), az emlőrák (R: 0,79) és a petefészekrák (RR: 0,61) kockázata az átlagos lakossághoz képest 
csökkent, a betegek elsőfokú rokonainál és gyermekeinél a kockázat azonos [23].

A jelenséget a tej/tejtermékek magas telített zsírsavés IGF-1-tartalmával magyarázzák, amelyek serkentik a sejtproliferációt, angiogenezist és csökkentik az apoptózist. Feltételezik a mikrobioma változását is. Nem ismert, hogy az LI-ben ismert polimorfizmusok mellett léteznek más genetikai eltérések, amelyek befolyásolják a daganatképződést.

A kutatások a galaktózról feltételezik az onkogén hatást: metabolitjai, a galaktóz-1-foszfát és a galaktilol, valamint az UDP-galaktóz gátolják a petefészekben az apoptózist és a gonadotropinok hatását [24].

Ellentmondásos az LI és CRC kapcsolata. Epidemiológiai tanulmányokból készült metaanalízisek szerint a tejtermékek fogyasztása csökkenti a CRC kockázatát $[25,26]$. Európai prospektív tanulmányban 477112 esetnél 11 év alatt 4513 CRC-esetet észleltek, és a tejtermékek, vagyis a kalcium fogyasztása csökkentette a CRC kockázatát [27]. Egy 2014-es metaanalízisben 15 tanulmány 900000 kontrollegyén és 5200 CRC-beteg adatai alapján a nem erjesztett tejtermékek fogyasztása csökkentette a CRC relatív kockázatát (RR: 0,74, 95\% KT: 0,60-0,91) férfiaknál. Nőknél és rectalis carcinomában a jelenség nem észlelhető [28]. Feltételezik a galaktózt kötő galektinek szerepét, amelyek részt vesznek a normális sejtmetabolizmusban, és a colonocytákban gátolják a lektinek proliferatív hatását [29].

Finn egyéneken kimutatták, hogy a C/C>13910 genotípusú egyéneknél a CRC kockázata magasabb (OR: 1,40, KT: 1,07-1,85), ellentétben a brit és spanyol lakossággal, ahol e kockázat azonos [30]. Olaszoknál szintén nem igazolták, hogy a C/T>13810 genotípus fokozza a CRC kockázatát [26]. További, több populációban végzett felmérés szükséges az LI és CRC kapcsolatának tisztázására.

\section{Laktózintolerancia és a gyógyszerek}

A gyógyszerészetben a laktóz fontos adalékanyag: számos készítmény tartalmaz különböző mennyiségben laktózt (10-750 mg), amelynek szerepe térfogatnövelő: a kis mennyiségű hatóanyag mellett elősegíti a tabletták, pilulák, kúpok készítését. A gyógyszerekben a laktóz monohidrát formában van jelen: a vegyület tiszta, vízben jól oldódik (160 g/l), íze édeskés, nem reagál kémiailag a hatóanyagokkal. Toxikus hatása nincs, patkányban az $\mathrm{LD}_{50}$ értéke $10000 \mathrm{mg} / \mathrm{kg}$. A vegyület mikrobiológiai tisztasága $<100 \mathrm{CFU/g}$, patogén kórokozókat (Escherichia coli, Pseudomonas aeruginosa, Staphylococcus aureus, Salmonella) nem tartalmaz. E tulajdonságok alapján szerepel az európai gyógyszerkönyv (European Pharmacopoeia) előző és a jelenlegi, 2015-ben megjelent 8. kiadásában, jelezvén, hogy az Európai Unió országaiban használata engedélyezett [31, 32].

A tejcukorérzékeny betegek többsége a kis adagban bevitt laktózt (8-12 g, azaz egy pohár tejben lévő meny- nyiséget) tünetek nélkül tolerálják [33]: ez többszöröse a gyógyszerekben lévő laktóznak. Más szerzők azonban ezt a mennyiséget 5 grammra becsülték [34], skandináv és amerikai szerzők az egyéni érzékenységre fektetik a hangsúlyt $[35,36]$ : a betegek egy része az igen kis menynyiségű laktózt sem tolerálja, és tekintetbe kell venni az úgynevezett nocebo hatást. Ez a placebo adása alatt jelentkező kellemetlen mellékhatásokat jelenti. Számos beteg többfajta gyógyszert szed: ezekben a laktóz összmennyisége meghaladhatja azt a határt, amely már panaszt okoz. A gyógyszerek mintegy 30\%-a mellékhatásként hasmenést okozhat: ennek okai igen változatosak. Néhány gyógyszerről azonban leírták, hogy tejcukorérzékenységet okozhatnak, illetve a meglévő LI tüneti exacerbatiójához vezetnek (kromoglikát, propicil, metiltiouracil, kolchicin) $[37,38]$ : esetbemutatásokról van szó, a téma szisztematikus áttekintése nem történt meg.

Külön figyelmet érdemel a kemoterápia indukálta LI. 1994-ben figyelték meg kevert daganatos betegcsoportban (CRC, tüdő-, emlő-, hólyagcarcinoma, lymphoma, leukémiák), hogy a kemoterápia során az esetek 35\%ában kóros $\mathrm{H}_{2}$-kilégzési görbét lehet kimutatni, bár az LI tünetei csak 10\%-ban jelentkeznek [39]. Állatkísérletekben az 5-FU, metotrexát és citozin-arabinozid károsította a bélepitheliumot; emberben a metotrexátról és citozin-arabinozidról igazoltak hasonló hatást $[40,41]$. Daganatos betegeknél a hasmenéshez az epesavak malabsorptiója, bakteriális túlnövekedés és pancreaselégtelenség is hozzájárulhat [42], ezért a laktózmentes étrend bevezetése az amúgy is alultáplált egyénekben csak az igazolt esetekben indokolt.

Az eddigi egyetlen nagyobb tanulmányban 150 CRCbeteg részesült Mayo- vagy De Gramont-kezelésben, a kezelés előtt, 2 hónappal és 6 hónappal a kemoterápia után (5-FU) laktóztolerancia-tesztet végeztek, tüneti és életminőség-kérdőívet töltöttek ki. Az LI gyakorisága kemoterápia előtt $25 \%$, azután $35 \%$, folyamatos infúzióban adott kezelés után $45 \%$ volt. A kemoterápia után kialakult másodlagos LI reverzibilis, a kezelés befejezésével fokozatosan megszünik [42].

LI jelentkezhet sugárkezelés után is: a radiációs enteritis során csökken a nyálkahártya laktáz- és szukrázaktivitása. A steatorrhoea, a vékonybél gyulladása és a bakteriális túlnövekedés itt is hozzájárulhat a tünetekhez [43]. A súlyos morfológiai elváltozásokkal járó radiációs enteritisben a másodlagos LI végleges.

Olasz tanulmányban 77 laktózérzékeny betegnél 400 mg laktóz, illetve azonos mennyiségú placebo adása után sem a típusos tünetek nem jelentkeztek, sem a $\mathrm{H}_{2}$-kilégzés értékei nem változtak, igazolva, hogy a kis mennyiségü laktózt a betegek tolerálják [44].

A gyógyszerek laktóztartalmáról tájékozódni lehet a Laktóz Érzékenyek Társaságának kiadványaiból és honlapjáról (http://www. laktozerzekeny.org), illetve az OGYI listájáról (http://www.ogyi.hu): mindkettőt rendszeresen frissítik és a gyógyszerek laktóztartalma fel van tüntetve: ebből a gyógyszereredetû napi laktózbevi- 
tel kiszámítható. A tejcukorérzékeny betegeket új gyógyszer bevezetése esetén tájékoztatni kell annak laktóztartalmáról, panaszok esetén vagy a beteg preferenciája alapján a gyószer laktózmentes változatát kell rendelni: ha ez nem áll rendelkezésre, enzimpótlás adható a magas laktóztartalmú gyógyszerek bevétele előtt, bár ez szakértői vélemény [8], és e téren nincsenek kontrollált tanulmányok.

\section{Diéta}

Az LI kezelésének alapköve a laktózmentes étrend, bár ennek hatásossága is vitatott $[1,2]$. Az érintett betegek érzékenysége tejcukor bevitelére széles határok között mozog. A tüneteket befolyásolja a táplálékkörnyezet is, amellyel a laktóz bekerül: az étel hőmérséklete, a péktermékek, a magas energiatartalmú ételek (zsiradékok) a gyomorürülés lassítása révén csökkenthetik az LI tüneteit.

A diéta egyik változata a laktózmentes vagy csökkent laktóztartalmú ételek fogyasztása. A tej laktóztartalma több módszerrel csökkenthető: pasztörizálással mérsékelt, ultracentrifugálással/szüréssel jelentős csökkenés érhető el. Ultracentrifugálással a laktózt maltodextrinnel helyettesítik. A laktóztartalom 0-2 grammra csökkenthető. Laktázenzim adagolása a tejben lévő laktóz 70$80 \%$-át hidrolizálja, de a tartósítás során a tej fehérjetartalma elvész a Maillard-reakció révén [8]. A reakciót 1912-ben írta le Louis-Camille Maillard (1878-1936), mivel az ételekben melegítés során az aldehidek reakcióba lépnek a DNS és fehérjék szabad $-\mathrm{NH}_{2}$-csoportjaival: a glükóz aldehidformája a fehérjékkel Schiff-bázisokat képez.

A csökkent laktóztartalmú termékekkel végzett kontrollált tanulmányokban azonban éppen a változó egyéni tolerancia miatt nem sikerült kimutatni egyértelmúen pozitív hatásukat az LI tüneteire [2].

Számos tanulmány született a joghurtról. 1974-ben figyelték meg, hogy az erjesztett tejtermékek hatásosak az LI tüneteinek mérséklésében. A fermentált tejtermékek jelentős mennyiségü, bakteriális béta-galaktozidázt (laktázt) tartalmaznak, amely a sejteken belül a tárolás során $\left(+4{ }^{\circ} \mathrm{C}, \mathrm{pH}=3-4\right)$ inaktív, de a duodenumban testhőmérsékleten, a pH 7-8-as értékeinél aktiválódik és lebontja a laktózt $[8,45]$. A joghurtban Lactobacillus bulgaricus és Streptococcus thermophilus van: ezek a bélben több óráig elélnek, de hatásuk $\mathrm{pH}$-dependens, $\mathrm{pH}=$ 7 értéknél, $37{ }^{\circ} \mathrm{C}$-on a laktóz 95\%-át hidrolizálják. Az epe segíti az enzimaktivitást: in vitro kimutatták, hogy növeli a baktérium falának permeabilitását, így a szubsztrátum hozzáférését is. 1982-től több tanulmány igazolta, hogy a megfelelő baktériumszámot tartalmazó joghurtnak kedvező hatása van az LI tüneteiben. Ezzel ellentétben a Lactobacillus acidophilus-tenyészet hozzáadása a tejhez több tanulmányban hatástalan volt.

Fontos a rejtett laktóztartalom felismerése is: egyes betegekben az intolerancia olyan fokú, hogy még a nyo- mokban jelen lévő laktóz is panaszt okoz. Hasznos az olyan vásárlói magatartás, amikor a vevő minden terméken ellenőrzi a laktóztartalmat: még így is érheti a beteget meglepetés.

Nemzetközi irányelvek és konszenzusok híján a tejcukorérzékeny betegek diétáját egyénre szabottan kell öszszeállítani. Optimális lenne, ha a betegek diétáját - legalábbis a betegség kezdeti szakaszában - szakképzett dietetikus vezetné: ezt csupán a betegek töredéke veszi igénybe.

\section{Enzimpótlás}

Az élettani ismeretek fejlődésével néhány emésztőszervi betegségben lehetővé vált az enzimpótlás. Története majdnem 120 éves: elsőként a hasnyálmirigy-betegségek kezelésében vezették be a pancreaskivonatok adását. A sósav-pepszin oldatot a XX. század első évtizedeiben használták digestivumként achilia gastricában; egyes szerzők még borban oldott pepszint is ajánlottak, holott az alkohol inaktiválta a fermentumot (2. táblázat). Laktázkivonatokat a XX. század elején készítettek emberi és állati vékonybélból, az enzimpótlás csak az 1980-as években jelent meg [46]. A gyógyszertárakban forgalmazott laktázkészítményeket a Kluyveromyces fragilis és lactis penészból és az Aspergillus oryzae és niger gombákból vonják ki. A gyógyszerek kiszerelése változó: a hazai gyógyszerpiacon kapható termékek adatai a 3. táblázatban szerepelnek. A készítményekben lévő laktáznak elméletileg közömbösítenie kellene a táplálékban lévő laktóz okozta panaszokat; a kontrollált tanulmányok eredményei azonban ellentmondásosak. A 2010-es amerikai összefoglaló 26 dolgozatban megjelent eredményeket értékelte ki. A betegeknek kereskedelmi forgalomban lévő laktázkészítményt vagy az elfogyasztott tejhez béta-galaktozidázt adtak. A hatást $\mathrm{H}_{2}$-kilégzési teszttel és a vizelet galaktózszintjének mérésével értékelték ki. A dolgozatok esetszáma 6-150 között volt, módszertanilag igen különböztek, ezért általános következtetéseket nem vonhattak le: egyes betegcsoportokban a laktáz kedvező hatása igazolható volt, másokban nem. Kedvező hatás esetén megfigyelték annak átmeneti jellegét. A nagyfokú heterogenitás miatt metaanalízis e témáról nem született: további jól tervezett tanulmányokra van szükség a laktázkészítmények hatásosságának igazolására [2]. A rettegett FDA a laktázkészítmények használatáról még nem foglalt állást [47]. Nincs kialakult vélemény arról sem, hogy LI-ben milyen legyen a diéta és az enzimpótlás aránya: vannak, akik a laktóztartalmú étrend mellett állandó laktázpótlást, mások a laktózmentes étrend mellett az alkalmi enzimpótlást javasolják: a kettő összehasonlítása még nem történt meg. Addig is, amíg az ismeretek kikristályosodnak, a laktázkészítmények egyénre szabott fogyasztása javasolt. Pozitív hatásuk mellett biztonságosak, a mellékhatások ritkák. Terhességben, szoptatásban az alkalmazási eloórás szerint ellenjavalltak, bár terheseknél nem történtek vizsgálatok. 
2. táblázat | Enzimpótlás emésztőszervi betegségekben

\begin{tabular}{|c|c|c|c|c|c|}
\hline Kórkép & Ok & Enzimhiány & Enzimpótlás & Történet & $\begin{array}{l}\text { Megjegyzés, } \\
\text { mellékhatások }\end{array}$ \\
\hline Pancreaselégtelenség & $\begin{array}{l}\text { Pancreatitis chronica, } \\
\text { tumor, mútét, cisztás } \\
\text { fibrosis }\end{array}$ & $\begin{array}{l}\text { Amiláz, lipáz, } \\
\text { proteázok }\end{array}$ & $\begin{array}{l}\text { Sertéspancreas- } \\
\text { kivonat, rekombináns } \\
\text { készítmény fejlesztése } \\
\text { folyamatban }\end{array}$ & $\begin{array}{l}\text { 1897-ben az AG } \\
\text { Rhenania cég } \\
\text { készítette az elsô } \\
\text { pancreaskivonatot } \\
\text { (Pankreon) }\end{array}$ & $\begin{array}{l}\text { Allergia, bélstrictura, } \\
\text { húgysavemelkedés. } \\
\text { Muszlimok } \\
\text { sertéseredetű } \\
\text { gyógyszert nem } \\
\text { fogyasztanak }\end{array}$ \\
\hline Atrophiás gastritis & $\begin{array}{l}\text { Pepszinogént termelő } \\
\text { sejtek pusztulása }\end{array}$ & Pepszinogén I-II & Pepszin & $\begin{array}{l}\text { Az 1878-ban } \\
\text { felfedezett pepszint } \\
\text { évtizedekig adták } \\
\text { gyomor- } \\
\text { betegségekben } \\
\text { különböző galenikus } \\
\text { formában }\end{array}$ & $\begin{array}{l}\text { Elavult, nem } \\
\text { használják }\end{array}$ \\
\hline Laktózintolerancia & $\begin{array}{l}\text { Elsődleges és } \\
\text { másodlagos } \\
\text { hypolactasia }\end{array}$ & Laktáz & $\begin{array}{l}\text { Gomba, élesztő és } \\
\text { gombaeredetű laktáz; } \\
\text { rekombináns } \\
\text { készítmény fejlesztése } \\
\text { folyamatban }\end{array}$ & $\begin{array}{l}\text { 1980-ban Aspergillus } \\
\text { oryzae gombából } \\
\text { vonták ki a béta-D- } \\
\text { galaktozidázt }\end{array}$ & $\begin{array}{l}\text { Ritkán allergia, } \\
\text { dyspepsia } \\
\text { (foglalkozási betegség } \\
\text { is lehet) }\end{array}$ \\
\hline $\begin{array}{l}\text { Veleszületett } \\
\text { szukráz-izomaltáz- } \\
\text { hiány }\end{array}$ & $\begin{array}{l}\text { Ritka autoszomális } \\
\text { recesszíven öröklődő } \\
\text { betegség, oka a } 3 . \\
\text { kromoszómán lévő } \\
\text { gén mutációja }\end{array}$ & $\begin{array}{l}\text { Szukráz-izomaltáz } \\
\text { hiánya }\end{array}$ & $\begin{array}{l}\text { Gombaeredetü } \\
\text { szakrozidáz }\end{array}$ & $\begin{array}{l}\text { Az 1960-ban leírt } \\
\text { betegség kezelésére } \\
\text { 1999-ben adták a } \\
\text { szakrozidázt }\end{array}$ & $\begin{array}{l}\text { A szakrozidáz hatásos } \\
\text { az enzimhiány } \\
\text { tüneteinek } \\
\text { kezelésében. } \\
\text { Grönlandon gyakori } \\
(10 \%)\end{array}$ \\
\hline Rövid bél szindróma & Kiterjedt bélreszekció & $\begin{array}{l}\text { Pancreasenzim és } \\
\text { laktázpótlás }\end{array}$ & & - & - \\
\hline Fruktózintolerancia & $\begin{array}{l}\text { A fruktóz elégtelen } \\
\text { felszívódása a } \\
\text { GLUT-5 transzporter } \\
\text { elégtelen múködése } \\
\text { vagy túlzott } \\
\text { fogyasztás miatt }\end{array}$ & $\begin{array}{l}\text { A xilóz-izomeráz } \\
\text { reverzibilisen alakítja } \\
\text { át a fruktózt } \\
\text { glükózzá. }\end{array}$ & $\begin{array}{l}\text { Bacteroides vulgatus, } \\
\text { Paraprevotella } \\
\text { xylaniphila, } \\
\text { Saccharomyces } \\
\text { cervisiae-böl kivont } \\
\text { enzim }\end{array}$ & $\begin{array}{l}\text { Az enzimet 1953-ban } \\
\text { fedezték fel, } \\
\text { Lactobacillus brevisből } \\
\text { kristályosították, de az } \\
\text { ipari elóállítása csak } \\
\text { 2002-ben sikerült }\end{array}$ & $\begin{array}{l}\text { Az enzim csökkenti a } \\
\mathrm{H}_{2} \text {-kilégzési értékeket } \\
\text { és a } \\
\text { fruktózfelszívódási } \\
\text { zavar tüneteit }\end{array}$ \\
\hline $\begin{array}{l}\text { l-es típusú Gaucher- } \\
\text { betegség }\end{array}$ & $\begin{array}{l}\text { Ritka autoszomális } \\
\text { recesszív betegség } \\
\text { miatt cerebrozidok } \\
\text { rakódnak le a májban } \\
\text { és lépben }\end{array}$ & $\begin{array}{l}\text { Glukocerebro- } \\
\text { zidázhiány az } 1 . \\
\text { kromoszómán lévő } \\
\text { gén mutációja miatt }\end{array}$ & $\begin{array}{l}\text { Algluceráz, } \\
\text { imigluceráz } \\
\text { velagluceráz }\end{array}$ & $\begin{array}{l}\text { Philip Charles Ernest } \\
\text { Gaucher (1854- } \\
\text { 1918) párizsi orvos } \\
\text { leírása után (1882) } \\
\text { 1913-ban nevezték } \\
\text { róla el a kórképet }\end{array}$ & $\begin{array}{l}\text { Görcskészség, } \\
\text { antitestképződés. } \\
\text { Askenázi zsidókban } \\
\text { gyakori ( } 1 \text { eset/450 } \\
\text { születés) }\end{array}$ \\
\hline
\end{tabular}

Allergiás reakciókat leírtak mind kezelt LI-ben, mind foglalkozási ártalomként: laktázkészítményeket gyártó dolgozóknál légzőszervi panaszok (rhinitis, asthma, conjunctivitis, kontakt dermatitis) jelentkezhetnek [48]. Egyes készítmények 30-200 mg glükózt tartalmaznak: szigorú diétán lévő cukorbetegeknél ezzel számolni kell.

A jövedelmi viszonyoktól függóen anyagi gondok is felmerülhetnek. Mivel csak két készítmény van gyógyszerként törzskönyvezve (3. táblázat), a többi táplálékkiegészítőként teljes áron szerezhető be: állandó használatuk tetemes költséget jelenthet.

\section{Colonadaptáció}

$\mathrm{Az}$ allergiás betegségekben használt deszenzibilizálás mintájára két tanulmányban próbálkoztak a laktóz emelkedő adagban való adásával a vastagbél-adaptáció eléré- sével. A laktóz emelkedő adagban való adása $(0,2 \mathrm{~g} / \mathrm{kg}$, $0,5 \mathrm{~g} / \mathrm{kg}, \mathrm{lg} / \mathrm{kg}$ ) több héten át nem enyhítette az LI tüneteit, és nem csökkentette a $\mathrm{H}_{2}$-kilégzés értékeit, ezért a módszert nem ajánlják [2]. Emberben a laktázenzim nem indukálható; ugyanakkor a vastagbél a motilitás és a bélflóra változásával bizonyos mértékben tud alkalmazkodni a laktózbevitelhez. E téren is további tanulmányok szükségesek.

\section{Probiotikumok}

A bélbaktériumokban és probiotikumokban lévő laktáz lebontja a laktózt: az így keletkezett glükózt és galaktózt a baktériumok felveszik és fermentálják: ebból laktát, hidrogén, metán, szén-dioxid és rövid láncú zsírsavak keletkeznek. A probiotikumokról 8 randomizált tanulmány született 8-40 fős esetszámmal; a módszertani különbsé- 
3. táblázat | A Magyarországon gyógyszertárakban forgalmazott laktázkészítmények jellemzői (gyógyszertári adatok, 2015.08.07.)

\begin{tabular}{|c|c|c|c|c|c|c|}
\hline Cég & Név & Kiszerelés & $\begin{array}{l}\text { Egység } \\
(\text { FCC })^{*}\end{array}$ & Adagolás & $\begin{array}{l}\text { Ár } \\
(\mathrm{Ft})\end{array}$ & $\begin{array}{l}\text { Támogatás }(\mathrm{Ft}) \text {, } \\
\text { rendelhetőség** }\end{array}$ \\
\hline Strathmann KG & $\begin{array}{l}\text { Lactase } \\
\text { rágótabletta }\end{array}$ & $\begin{array}{l}50 \mathrm{db}, 100 \mathrm{db} \\
\text { rágótabletta }\end{array}$ & 2900 & $\begin{array}{l}1 \text { rágótabletta } \\
10 \mathrm{~g}(2 \mathrm{dl} \text { tej }) \\
\text { laktózhoz }\end{array}$ & $\begin{array}{l}4851 \\
(21,83 / d b)\end{array}$ & $\begin{array}{l}\text { v., } 100 \mathrm{db}, \\
\text { általános támogatás, } \\
\text { közgyógyellátás } \\
\text { terhére rendelhető }\end{array}$ \\
\hline Strathmann KG & Laluk 4500 & $\begin{array}{l}10 / 30 \mathrm{db} \\
\text { kapszula }\end{array}$ & 4500 & $\begin{array}{l}1 \text { kapszula } 3 \mathrm{dl} \text { tejben } \\
\text { lévő laktózhoz }\end{array}$ & 2195 & v. n. \\
\hline TEVA & Millandjoy & $\begin{array}{l}250 \mathrm{mg} \text { rágó- } \\
\text { tabletta, } 20 \mathrm{db}\end{array}$ & 4500 & $\begin{array}{l}1-2 \text { rágótabletta } \\
12 \mathrm{~g} \text { tejcukorhoz }\end{array}$ & 1395 & v. n. \\
\hline JuvaPharma & $\begin{array}{l}\text { JutaVit Laktáz } \\
\text { enzim tabletta }\end{array}$ & $60 \mathrm{db}$ kapszula & 5000 & $\begin{array}{l}1 \text { tabletta } \\
10 \text { g laktózt bont le }\end{array}$ & 1195 & v. n. \\
\hline BrandUp Pharma Kft. & Lactase Comfort & $10 \mathrm{ml} / 200 \mathrm{csepp}$ & 4500 & $\begin{array}{l}\text { 5-10 csepp } 1 \text { liter } \\
\text { tejben lévő laktózhoz }\end{array}$ & 4709 & $\begin{array}{l}\text { v. n. vagy v., } \\
\text { általános támogatással, } \\
2119\end{array}$ \\
\hline $\begin{array}{l}\text { Sciotec Diagnostic } \\
\text { Technologies, } \\
\text { Ausztria }\end{array}$ & $\begin{array}{l}\text { Lactosolv, } \\
\text { Lactosolv Forte }\end{array}$ & $30 \mathrm{db}$ kapszula & $\begin{array}{l}9250 \\
17500\end{array}$ & $\begin{array}{l}1 \text { kapszula } 50 \mathrm{~g} \\
\text { laktózt bont le }\end{array}$ & 3090 & v. n. \\
\hline Medico Uno & Co-Lactase & $10 \mathrm{ml} / 200$ csepp & 4500 & $\begin{array}{l}10 \text { csepp } \\
12 \mathrm{~g} \text { laktózt bont le }\end{array}$ & 2706 & v. n. \\
\hline
\end{tabular}

*FCC: Food Chemical Codex, az amerikai Pharmacopoeia által leírt, a gyógyszerek hatóanyagaira vonatkozó minőségi követelmények kézikönyve. ** v.: a támogatott termék vényköteles; v. n.: vény nélkül.

gek miatt metaanalízist nem sikerült készíteni. Tüneti eredmény ott érhető el, ahol $10^{9} \mathrm{CFU} / \mathrm{ml}$ Lactobacillus acidophilus-vagy bulgaricus-, illetve Bifidobacterium-tartalmú probiotikumot adagoltak a tejhez. Nem használtak kereskedelmi forgalomban lévő probiotikumot. A tüneti javulás és a $\mathrm{H}_{2}$-kilégzési értékek csökkenése szerény volt [2]. A gyakorlati eredmények ellentmondásban vannak a kutatásokkal, amelyek szerint a probiotikumok baktériumaiban lévő laktáz pótolja az intestinalis enzimet [49]. Kanadai-magyar szerző szerint a laktóz tk. prebiotikum, azaz a normális bélflóra fejlődéséhez szükséges vegyület [50]. Hazánkban több mint egy tucat probiotikum van forgalomban, egyiknek sincs kiértékelve hatása tejcukor-érzékenységben. Szedésük nem helyettesíti sem a diétát, sem az enzimpótlást.

\section{Szociális ellátás}

Felismerve a tejcukorérzékeny betegek életminőségének csökkenését és a fogyatékossággal járó többletköltségeket, az egészségügyi kormányzatok több intézkedéssel igyekeznek segíteni: ezek mértéke országonként változik. ben.

Magyarországon az alábbi rendeletek vannak érvény-

\section{Adócsökkentés, emelt családi pótlék}

Az 1995. évi CXVII. törvény 81. paragrafus 2. bekezdése alapján a tejcukorérzékenység elsődleges és másodlagos vagy egyéb formája (ez nem tudni, mit takar) súlyos fogyatékosságnak minősül. A 335/2009 (XII. 19.) kormányrendelet alapján az adóköteles jövedelemmel rendelkező betegek összevont adóalapja csökkenthető: ennek mértéke fokozatosan növekedett a minimálbérrel, a kezdeti körülbelül havi 3250 Ft-ról a jelenlegi 5250 Ft-ra. A rendelet részletes szövege elérhető a Laktóz Érzékenyek Társaságának honlapján és kiadványaiban, a Hatályos Jogszabályok Gyưjteményében, a Magyar Közlönyben és az Egészségügyi Közlönyben; ennek dacára csak a betegek egy része él lehetőségével.

Gyermekeknél igényelhetô az emelt színtű családi pótlék. A rendelet célja, hogy hozzájáruljon a laktózmentes étrend többletköltségének csökkentéséhez. Ismeretes, hogy a laktózmentes táplálkozás azonos készítmények esetén havonta több mint $10000 \mathrm{Ft}$ többletköltséget jelent a normális készítményekkel szemben.

\section{Gyógyszerár-támogatás}

Igazolt LI esetében a Lactase az egyetlen készítmény, amely általános támogatással rendelhető, mivel csak az rendelkezik gyógyszer minősítéssel (3. táblázat). A többi készítmény gyógyászati célra szánt tápszerként került notifikálásra az OÉTI-nél, így nem részesül támogatásban, teljes áron megvehető, többségük a forgalmazó cégektől akár interneten is megrendelhető. Amennyiben a betegnél a táplálékfelvétel és -felhasználás súlyos károsodásával járó kórkép megállapítható, úgy a laktózmentes tápszerek 90\%-os egészségügyi térítéssel rendelhetők: ez szerencsére ritka izolált LI-ben, de gyermekeknél vagy coeliakiával, Crohn-betegséggel társulva és kemoterápia után előfordulhat. 


\section{Egyesïletek, társasági élet}

Az LI-ellátásnak és tájékoztatásának javítására a lisztérzékenységhez hasonlóan alapítványt létesítettek.

A Laktóz Érzékenyek Társaságát (http://www.laktozerzekeny.org) 1995-ben alapította 10 magánszemély, munkájukat a továbbiakban 23 önkéntes segítette. A társaság célkitűzése a táplálkozási információk terjesztése az LIben szenvedő betegek körében és a betegek érdekvédelme. A szervezet jellege közhasznú. Múködését a támogató személyek jövelemadójának 1\%-a, cégek, a budapesti IV. kerületi Önkormányzat, magánszemélyek adományai és hirdetések biztosítják. A társaság jelenlegi taglétszáma csupán 457, de honlapján 1927 fó regisztrált, a látogatók száma 257998 fó volt (2015. szeptember 30-án). Olvasói számára rendszeresen küld információs anyagot az LI tüneteiről, hosszú távú következményeiről, az újabb laktózmentes élelmiszerekról, az enzimpótlásról, de rendszeresen ismerteti az LI-betegeket érintő kedvezményeket is. Eddig 77 tájékoztatója jelent meg, többségükben olyan aktuális információkkal, amelyek máshol nem érhetők el. Formális kapcsolata a Magyar Gasztroenterológiai Társasággal, Magyar Táplálkozástudományi Társasággal, Magyar Dietetikusok Országos Szövetségével, az Országos Élelmezés- és Táplálkozástudományi Intézettel nincs, pedig a kétoldalú kapcsolatok javíthatnák a betegek tájékoztatását és ellátását, sőt gyarapíthatnák az LIvel foglalkozó orvosok ismereteit is.

Anyagi támogatás: A szerző a közlemény megírásáért anyagi támogatásban nem részesült.

A cikk végleges változatát a szerző elolvasta és jóváhagyta.

Érdekeltségek: A szerzőnek nincsenek érdekeltségei.

\section{Köszönetnyilvánítás}

A szakirodalom beszerzésében nyújtott segítségért köszönet illeti $S z i$ lágyi Annát (Semmelweis Egyetem, Élettan Intézet). A szövegszerkesztés Józan Jolán munkáját dicséri. Vancza Róbert gyógyszerész úrnak (Sors Bona patika) köszönöm a laktáztermékekre vonatkozó adatszolgáltatást. A Laktóz Érzékenyek Társaságára vonatkozó adatokat köszönöm Bárdos György úrnak.

\section{Irodalom}

[1] Lomer, M. C., Parkes, G. C., Sanderson, J. D.: Review article: lactose intolerance in clinical practice - myths and realities. Aliment. Pharmacol. Ther., 2008, 27(2), 93-103.

[2] Wilt, T. J., Shaukat, A., Shamliyan, T., et al.: Lactose tolerance and health. Evid. Rep. Technol. Assess (Full Report), 2010, 192, $1-410$.

[3] Milk chemistry. An introduction. http://www.ilri.org/InfoServ/Webpub/fulldocs/ilcamanual4/Milkchemistry

[4] Guéguen, L., Pointillart, A.: The bioavailability of dietary calcium. J. Am. Coll. Nutr., 2000, 19(Suppl. 2), 119S-136S.
[5] Rizzoli, R.: Dairy products, yogurts and bone health. Am. J. Clin. Nutr., 2014, 99(5 Suppl.), 1256S-1262S.

[6] Pansu, D., Chapuy, M. C.: Calcium absorption enhanced by lac tose and xylose. Calcif. Tissue Res., 1970, 4(Suppl.), 155-156.

[7] Kocián, J., Skála, I., Bakos, K.: Calcium absorption from milk and lactose-free milk in healthy subjects and patients with lactose intolerance. Digestion, 1963, 9(4), 317-324.

[8] Gudmand-Hoyer, E.: The clinical significance of disaccharide maldigestion. Am. J. Clin. Nutr., 1994, 59(3) Suppl., 735S$741 S$.

[9] Cochet, B., Jung, A., Griessen, M., et al.: Effects of lactose on intestinal calcium absorption in normal and lactase-deficient subjects. Gastroenterology, 1983, 84(5 Pt 1), 935-940.

[10] Newcomer, A. D., Hodgson, S. F., McGill, D. B., et al.: Lactase deficiency: prevalence in osteoporosis. Ann. Int. Med., 1978, 89(2), 218-220.

[11] Horowitz, M., Wishart, J., Mundy, L., et al.: Lactose and calcium absorption in postmenopausal osteoporosis. Arch. Intern. Med., 1987, 147(3), 534-536.

[12] Curate, F.: Osteoporosis and paleopathology: a review. J. Anthropol. Sci., 2014, 92, 119-146.

[13] Józsa, L.: Paleopathology. Diseases of our ancestors. [Paleopathologia. Elődeink betegségei.] Semmelweis Kiadó, Budapest, 2006. [Hungarian]

[14] Schmid, A., Walther, B.: Natural vitamin D content in animal products. Adv. Nutr., 2013, 4(4), 453-462.

[15] Appleby, P., Roddam, A., Allen, N., et al.: Comparative fracture risk in vegetarians and nonvegetarians in EPIC-Oxford. Eur. J. Clin. Nutr., 2007, 61(12), 1400-1406.

[16] Tolonen, S., Laaksonen, M., Mikkilä, V., et al.: Lactase gene $\mathrm{C} / \mathrm{T}_{-13910}$ polymorphism, calcium intake and pQCT bone traits in Finnish adults. Calcif. Tissue Int., 2010, 88(2), 153-161.

[17] Bácsi, K., Kósa, J. P., Lazáry, A., et al.: LCT 13910 C/T polymorphism, serum calcium and bone mineral density in postmenopausal women. Osteoporos. Int., 2009, 20(4), 639-645.

[18] Manios, Y., Moschonis, G., Trovas, G., et al.: Changes in biochemical indexes of bone metabolism and bone mineral density after a 12-mo dietary intervention program: the Postmenopausal Health Study. Am. J. Clin. Nutr., 2007, 86(3), 781-789.

[19] Kruger, M. C., Schollum, L. M., Kuhn-Sherlock, B., et al.: The effect of fortified milk drink on vitamin $\mathrm{D}$ status and bone turnover in post-menopausal women from South East Asia. Bone, 2010, 46(3), 759-767.

[20] Bonjour, J. P., Benoit, V., Rousseau, B., et al.: Consumption of vitamin D and calcium-fortified soft white cheese lowers the biochemical marker of bone resorption TRAP $5 \mathrm{~b}$ in postmenopausal women at moderate risk of osteoporosis fracture. J. Nutr., 2012, 142(4), 698-703.

[21] Cramer, D. W.: Lactase persistence and milk consumption as determinants of ovarian cancer risk. Am. J. Epidemiol., 1989, 130(5), 904-910.

[22] Larsson, S. C., Orsini, N., Wolk, A.: Milk, milk products and lactose intake and ovarian cancer risk: a meta-analysis of epidemiological studies. Int. J. Cancer, 2006, 118(2), 431-441.

[23] Ji, J., Sundquist, J., Sundquist, K.: Lactose intolerance and risk of lung, breast and ovarian cancers: aetiological clues from a population-based study in Sweden. Br. J. Cancer, 2015, 112(1), 149152.

[24] Liu, G., Hale, G. E., Hughes, C. L.: Galactose metabolism and ovarian toxicity. Reprod. Toxicol, 2000, 14(5), 377-384.

[25] Aune, D., Lau, R., Chan, D. S., et al.: Dairy products and colorectal cancer risk: a systematic review and meta-analysis of cohort studies. Ann. Oncol., 2012, 23(1), 37-45.

[26] Tarabra, E., Pazienza, P., Borghesio, E., et al.: LCT $_{-13910} \mathrm{C}>\mathrm{T}$ polymorphism-associated lactose malabsorption and risk for colorectal cancer in Italy. Dig. Liver Dis, 2010, 42(10), 741743.

[27] Murphy, N., Norat, T., Ferrari, P., et al.: Consumption of dairy products and colorectal cancer in the European Prospective Investigation into Cancer and Nutrition (EPIC). PloS ONE, 2013, $8(9)$, e72715. 
[28] Ralston, R. A., Truby, H., Palermo, C. E., et al.: Colorectal cancer and nonfermented milk, solid cheese, and fermented milk consumption: a systematic review and meta-analysis of prospective studies. Crit. Rev. Food Sci. Nutr., 2014, 54(9), 1167-1179.

[29] Hasan, S. S., Ashraf, G. M., Banu, N.: Galectins - potential targets for cancer therapy. Cancer Lett., 2007, 253(1), 25-33.

[30] Rasinperä, H., Forsblom, C., Enattah, N. S., et al.: The C/C -13910 genotyope of adult-type hypolactasia is associated with an increased risk of colorectal cancer in the Finnish population. Gut, $2005,54(5), 643-647$.

[31] Reagents, Chemicals and Labware. [Laktóz-monohidrát.] http://www.merckmillipore.com/HU/hu/product/ 2015.07.17. [Hungarian]

[32] Vecsernyés, M., Kovácsné Bácskay, I., Sipos, T., et al.: Prescriptionbased medicine preparation. Part III. Materials. [Recepturai gyógyszerkészítés: III. rész. Anyagismeret.] Debreceni Egyetemi Kiadó, Debrecen, 2011. [Hungarian]

[33] Shaukat, A., Levitt, M. D., Taylor, B. C., et al.: Systematic review: effective management strategies for lactose intolerance. Ann. Intern. Med., 2010, 152(12), 797-803.

[34] Arola, H., Tamm, A.: Metabolism of lactose in the human body. Scand J. Gastroenterol., 1994, 202(Suppl.), 21-25.

[35] Bedine, M. S., Bayless, T. M.: Intolerance of small amounts of lactose by individuals with low lactase levels. Gastroenterology, $1973,65(5), 735-743$

[36] Gudmand-Hoyer, E., Simony, K. L.: Individual sensitivity to lactose in lactose malabsorption. Am. J. Dig. Dis., 1977, 22(3), $177-181$

[37] Brandstetter, R. D., Conetta, R., Glazer, B.: Lactose intolerance associated with Intal capsules. N. Engl. J. Med., 1986, 315(25), 1613-1614

[38] Petrini, L., Usai, P., Caradonna, A., et al.: Lactose intolerance following antithyroid drug medications. J. Endocrinol. Invest., 1997, 20(9), 569-570

[39] Parnes, H. L., Fung, E., Schiffer, C. A.: Chemotherapy-induced lactose intolerance in adults. Cancer, 1994, 74(5), 1629-1633.

[40] Trier, J. S.: Morphologic alterations induced by methotrexate in the mucosa of human proximal intestine. I. Serial observations by light microscopy. Gastroenterology, 1962, 42, 295-305.
[41] Slavin, R. E., Dias, M. A., Saral, R.: Cytosine arabinoside in duced gastrointestinal toxic alterations in sequential chemotherapeutic protocols: a clinico-pathologic study of 33 patients. Cancer, 1978, 42(4), 1747-1759.

[42] Andreyev, H. J., Davidson, S. E., Gillespie, C., et al.: Practice guidance on the management of acute and chronic gastrointestinal problems arising as a result of treatment for cancer. Gut, 2012, 61(2), 179-192.

[43] Montalto, M., Gallo, A., Santoro, L., et al.: Low-dose lactose in drugs neither increases breath hydrogen excretion nor causes gastrointestinal symptoms. Aliment. Pharmacol. Ther., 2008, 28(8), 1003-1012

[44] Beer, W. H., Fan, A., Halsted, C. H.: Clinical and nutritional implications of radiation enteritis. Am. J. Clin. Nutr., 1985, 4l(1), 85-91.

[45] Savaiano, D. A.: Lactose digestion from yogurt: mechanism and relevance. Am. J. Clin. Nutr., 2014, 99 (5 Suppl.), 1251S-1255S.

[46] Di Palma, J. A., Collins, M. S.: Enzyme replacement for lactose malabsorption using a beta-D-galactosidase. J. Clin. Gastroenterol., 1989, 11(3), 290-293.

[47] Problems digesting dairy products? Food and Drug Administration, Consumer Health Information, U.S. New Hampshire, 2009. http://www.digestive.niddk.nih.gov/ddiseases/pubs/ lactoseintolerance

[48] Stöcker, B., Grundmann, S., Mosters, P., et al.: Occupational sensitization to lactase in the dietary supplement industry. Arch. Environ. Occup. Health, 2015 Jul 2. doi: 10.1080/19338244. 2015.1066294 [Epub ahead of print]

[49] De Vrese, M., Stegelmann, A., Richter, B., et al.: Probiotics - compensation for lactase insufficiency. Am. J. Clin. Nutr., 2001, 73(2 Suppl.), 421S-429S

[50] Szilágyi, A.: Redefining lactose as a conditional prebiotic. Can. J. Gastroenterol., 2004, 18(3) 163-167.

(Buzás György Miklós dr., Budapest, Mester u. 45., 1095 e-mail: drbgym@gmail.com)

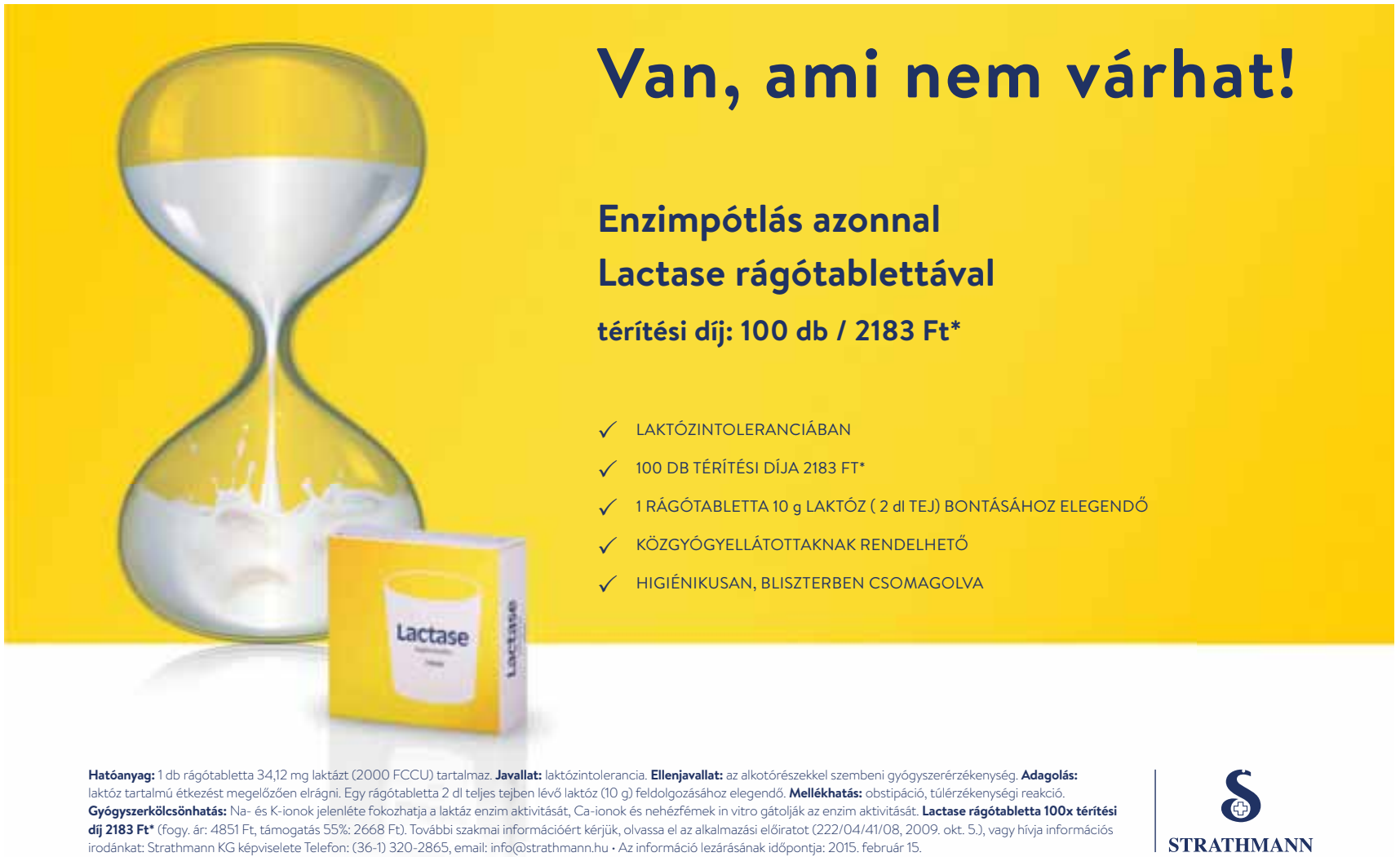

